\title{
Just War or Not: A Reassessment of the Korean War
}

\author{
Hoeun Choi
}

\begin{abstract}
The Korean War holds a significant place in the history of modern Korea. However, because it was a highly political and ideological conflict, it has been difficult to assess its true nature in a more-balanced, less-biased manner; both North and South Korea have argued for each side regarding the justness of the war. By reassessing the historical question of "Was the Korean War a just war?" this paper attempts to redefine the just-or-not question, since such a narrow viewpoint does not allow the forgotten parts of the Korean War to be revealed. By applying the just war theory and reassessing historical facts from a more historical perspective, this paper shows how unjust elements existed in both Koreas during the Korean War. Following demonstrations, this paper further suggests that it is more important and even necessary to consider wider perspectives and more historical factors in order to assess this major historical event from a more balanced viewpoint.
\end{abstract}

Index Terms-Historiography, history, Korea, Korean War.

\section{INTRODUCTION}

Long in its history, just war theory has evolved through centuries of interaction between different societies. With its beginnings rooted in religious principles, the theory has changed over time to involve other standards that have been established due to the advent of internationally accepted legal doctrines. The underlying tenets of just war theory deal with the justification in engaging in war with another country. The theory applies philosophical and legal principles to how and why wars are fought, thus allowing for an assessment of whether or not a war was 'just'.

In terms of philosophical principles, just war theory applies an ethical and moral standard in assessing a war's justifications, and the way a war is carried out. These standards originated during the times of the Greek and Roman philosophers, and were further developed by Christian theologians. Over time nations have incorporated aspects of such principles into legal doctrines found in international law such as the Geneva Convention, which establishes standards for the humanitarian treatment of war.

The legal standards of just war theory have arisen due to the historical lessons learned by societies. As nations that have endured periods of conflict, countries have worked together in setting international legal standards regarding war. A governing institution such as the United Nations is an example of this type of cooperation that focused its goals on taking measures that could avoid military conflict due to the wanton unilateral decision-making of a single nation.

Manuscript received July 10, 2013; revised September 20, 2013.

Hoeun Choi is with the Hankuk Academy of Foreign Studies, Korea (e-mail: isakhe@hanmail.net).

\section{THE KOREAN WAR}

The Korean War is generally regarded in the West as a just war [1]. War was clearly declared by a sovereign authority, and it was also an act against aggression from the communist regime in North Korea. No other intentions seemed to exist behind the goal of protecting democracy from communism.

Questioning this justification for the war is an unofficial taboo in contemporary South Korea [2]. The question of whether the Korean War was just or not has received relatively less attention than some of the other wars the United States had fought, such as the Vietnam War. Moreover, the Korean War was the first war in which various nations fought under the flag of the United Nations, which took legitimate steps to fight against communist forces. This fact also supports the notion that the Korean War was a just war against the aggression of the communists.

The current political situation regarding the region is that South Korea possesses one of the strongest economies in the world, and that North Korea has serious moral problems, such as its pursuit of nuclear weapons and its many violations of its people's basic human rights. This political situation is often used to suggest that South Korea is more just than North Korea, as well as to support South Korean actions during the Korean War. However, the just war theory raises serious doubts about current assumptions regarding the Korean War. Were the proper steps taken by the United Nations when it was decided that it would support the democratic leaning south? Were the ideological reasons for engaging in the war legitimate enough to make the war 'just'? As much as the north was responsible for morally suspect atrocities during the course of the war, was the south not just as culpable in certain instances? Furthermore, the assessment of the war based more on historical conditions during the war itself has been overshadowed by political considerations. By reassessing several significant conditions of the Korean War, this research aims to offer a different lens through which the war may be assessed under just war principles.

At its simplest form, just war theory maintains two sets of criteria [3]: jus ad bellum and jus in Bello. Jus ad bellum deals with a nation's right to go to war, while jus in Bello deals with proper conduct during the course of war. Within these two criteria there are several sub-categories that will be addressed in context with the Korean War.

\section{A. Jus AD Bellum: Sovereign Authority}

The first criterion within Jus Ad Bellum is the notion of just authority [3]-[5]. A war must be initiated by a sovereign authority for it to be considered just. This means that the sovereign authority must be legitimized within a political system centered on justice. Governments like the United States and the United Kingdom have political systems that require their leaders to be chosen through a democratic process. In addition, these systems provide safeguards that 
require accountability from their leaders. This is the type of sovereign authority required under the jus ad bellum criterion Regimes that fall under dictatorships fail to meet this standard. Under a dictatorship one individual sets all of rules, and in many instances these rules do not heed the standard ideals of justice. For example, within the North Korean regime power is found in one individual, and there is no system in place that allows for accountability or regime change.

From the perspective of South Korea, the war was declared by its president, Syngman Rhee, and backed by its government, which was declared legitimate by the United Nations in 1948. However, this aspect of being legitimate has not been questioned very much, especially in South Korea. If we consider that each Korea was backed by the leading powers of the world at the time, it is important to consider whether those powers also followed legitimate steps to participate in the war. The mere fact that the UN was behind South Korea seems to pretty much prove the legitimacy of the authority, as the UN comprises of many nations and possesses a complex decision-making mechanism. However, even the sovereignty of the UN is not an unquestionable issue. The most persuasive argument is that the UN has violated its own charter in order to go to war. Article 32 of the UN Charter [6] states that "Any Member of the United Nations which is not a member of the Security Council or any state which is not a Member of the United Nations, if it is a party to a dispute under consideration by the Security Council, shall be invited to participate, without vote, in the discussion relating to the dispute." Hence, the fact that North Korea was not invited as a temporary member indicates the possibility of the UN being biased, as only one side of the dispute was represented. Also, the fact that the Soviet Union boycotted the Security Council casts further doubt on the legitimacy of the UN and its actions. Although it is technically legal to make a decision when one of the permanent members of the Security Council is absent, except for vetoes, it would not be easy to avoid critical claims that the action was taken too quickly to satisfy the legitimacy issue, as such a matter would normally require the unanimous vote of all five Security Council states. In other words, it is not necessarily true that the UN decision regarding the Korean War reflected the balanced and unbiased voice of a sovereign body. Rather, the decision by the UN to participate in the Korean War was a decision representing the interests of Western powers rather than those of the entire UN, which leaves the legitimacy of the sovereign authority in question

\section{B. Jus AD Bellum: Just Cause and Intention}

Within jus ad bellum, the concept of a war having a just cause is considered to be the most important in justifying any war [3]-[5]. In order for just cause to be established, it must be demonstrated that a serious wrong has been committed by a nation that warrants military intervention. The current situation in Syria is a good example of whether there is just cause for military action. The use of chemical weapons by the Syrian regime against its own people has caused the United States and United Kingdom to determine whether military intervention is required. Does the use of chemical weapons by a nation against its own people establish just cause for military action? While the issue remains complex, the notion of just cause is at the center of decision-making process by the international community.

Historically, defense of one's nation after an invasion has always met the standard of just cause. In addition, defending one's ally against invasion has generally been accepted as a just cause to go to war. The onset of the Korean War clearly meets the criterion of just cause. On June $25^{\text {th }}$, 1950, the North Korean army launched a full-scale attack in the area around the 38th Parallel. For the South, it was evident that they had no other option but to fight back, because what happened was clearly a declaration of war. Also, South Korea was in no position to negotiate with the North, who was advancing down the peninsula at a horrific pace. The South's response was thus a response of last resort. Again, from a domestic perspective, there seems to be nothing doubtful about the South's war's cause and intention. From an international perspective, the cause the UN claimed to champion was the protection of South Korea from an illegitimate attack. In this sense, the UN also seems to be justified.

However, it is important to pay close attention to the fact that the United States was the leading nation arguing for mobilizing UN forces against North Korea, and that $88 \%$ of the UN peacekeeping force consisted of U.S. soldiers. Which also raises the question, which country's interests were really being served during the Korean War? Due to the influence the Cold War had on the United States, it was common practice for the United States to impose its interests on its allies. While South Korea's main interest was clearly to defend itself from the aggressive attack from the North, it is not difficult to see that the interests of the United States went far beyond that of mere survival.

The Korean War took place during the Cold War, when diplomatic tensions between the United States and the Soviet Union were prevalent in all aspects of life. For the United States, the victory of communism on the Korean peninsula meant the failure of the U.S.' containment policy in Southeast Asia. Therefore, preventing the spread of communism and protecting democracy in Korea was of crucial strategic importance for the United States, who sought to prevent other democratic nations from subsequently falling under the sway of the communists. Intervention for the U.S. was essentially the only option. This intervention did eventually prevent the spread of communism, but making the assertion that defending the ideology of one nation is just for other countries is controversial. In other words, it is hard for such an assertion to gain support as being universally just. Numerous wars in history were fought over beliefs and ideologies, such as the Crusades and World War II. Also, religious terrorists are also a representative example of modern ideological violence. As we can see, not only have most of the wars fought over differences in ideology been proven to be unjust, we can also assume that ideology alone cannot be an inherent justification for going to war. [3] In this particular case, it would be unjust for the United States to claim democracy as its cause, since it would then be asserting that its ideology is superior to others'.

In terms of just intention, this element of jus ad bellum serves to set a limit to the extent of a war. Despite the fact a nation may have a just cause to enter war, history has shown that nations can, and will go beyond the limits of their initial 
reasons for entering a conflict. The Korean War is an excellent example that shows a violation of this principle.

When the United Nations troops' attempted to reunify Korea by force under the leadership of General MacArthur, the objectives of the coalition had changed. Although the war began as a mission to repel the attacks form the North and restore peace on the peninsula, these goals were altered when the United States and their allies saw an opportunity to reunify the entire peninsula after MacArthur's victory in Incheon. As MacArthur continued to push north, the belief that reunification was possible became more viable. However, as history showed the change in objectives only compounded the problems behind the war. As the United States led forces continued to push farther north, China decided that it would involve itself in the war. Ultimately, the change in objectives led to more widespread conflict, and perhaps extended the war even longer. In hindsight, it's possible that it would have been better for the United States and its allies to maintain their initial objective of restoring peace rather than ambitiously trying to reunify the peninsula.

Taking all of these facts into consideration, the defense of democracy does not seem to have been a just cause for the U.S. going to war. However, let us assume that the cause could be somewhat justified when adding in the historical context that the North Korean communist regime was ruthless, and that the U.S. legitimately wanted to protect the South. Even though we assume that the U.S. did have a just cause, numerous pieces of historical evidence suggest that it clearly did not have a just intention. The alleged intention of the war was to establish a democracy and protect South Korea from tyranny. If this were true, South Korea would have easily established a democracy after the war, as the leading democracy in the world was there to help build a democratic government for its new ally. Ironically, South Korea suffered under the reign of three dictatorships over thirty-two years until the fall of President Chun in 1988. Although there were national-level strikes, such as the Gwangju Democratization Movement, the April 19 Revolution, and the June Democratic Movement, which were all nonviolent and enjoyed popular support, they were violently oppressed by the government, which used military forces against their own civilians, causing civilian casualties estimated to be in the thousands. While the prevalence of such a brutal tyranny was exactly what the U.S. claimed to be trying to prevent, tyrannical regimes were still very successful despite the U.S. presence. After all, the U.S. seemed more interested in trying to protect a pro-American ally, rather than a righteous democracy. As long as the regime remained loyal to the U.S., whether it was democratic or tyrannical was not a concern in the first place. It is therefore hypocritical for the U.S. to claim that its intentions were just.

\section{Jus AD Bellum: Last Resort}

The final element within jus ad bellum is the notion of war being the last resort [3]-[5]. Under this principle, war is justified only when it is the last option available to achieve just cause. In other words, all diplomatic and political solutions have been attempted. The United Nations is an example of one of the options that are used to avoid war. The U.N. has been known to apply sanctions upon nations as a way to avoid military conflict while still achieving a just cause such as deterrence. For example, in February 2013
North Korea announced that it had successfully conducted an underground nuclear test. The United Nations decided to apply sanctions in hopes that it would deter the regime from further developing its nuclear program. Another more recent example is the current case with Syria. Ever since conflict began within the country, the international community has watched closely. Despite the deaths that have been caused by President Assad and his regime, western powers like the United States and Great Britain have not taken action. They have used the United Nations as a way of involving the entire international community before any decision to intervene has been made. The principle function of the last resort criteria is to make sure that war will not be waged for reasons that may be unworthy of engaging in military conflict.

In terms of the Korean War, this criterion of just war theory is unquestionably met because South Korea had no choice but to defend itself from the hostile invasion of the North. By using any of the other aforementioned options to repel the North it would likely have been too late because the invasion was already underway and time was of the essence to restore peace and stability on the peninsula.

\section{Jus in Bello: Proportionality}

As mentioned above, just in Bello refers to the parameters set in order for conduct during the course of war to be considered just [3]-[5]. This criteria sets limits on what is acceptable during military conflict so as to create a state of controlled chaos. Doctrines such as the rules of engagement are examples of jus in Bello. During the course of war, many forces are required to avoid civilian casualties to the best of their abilities. Intentional killing of non-military lives is considered a clear violation of jus in Bello. This is why many armed forces have protocols that demand accountability in instances where their soldiers violate this principle. Recently, it was discovered that a United States soldier wantonly killed innocent civilians in Afghanistan. He was detained by his own military, and prosecuted for this atrocity.

The first criterion of jus in Bello is the concept of proportionality. Proportionality measures the degree of force used during war against the force that was necessary to meet the objectives of the just cause. Not surprisingly, it is difficult to really know whether the force that was used was truly the amount that was necessary. Granted in situations like World War II where the United States used atomic arsenal against Japan, a strong argument can be made regarding the level of force. However, when two nations with similar military capability are using similar methods during battle, it is generally accepted that the criterion of proportionality has been met. In the context of the Korean War, both North and South Korea had similar military arsenal at their disposal. While South Korea had the United States as its main ally providing military support, the North was not without its share of assistance. Although the Soviet Union did not actively participate in the war, they did provide medical and military supplies to the North Koreans. Many of the aircrafts that were used by the North Korean forces were Soviet MiG 15 fighter jets that were controlled by Soviet pilots. In addition, the North Korean forces also had assistance from China.

\section{E. Jus in Bello: Discrimination}

The term discrimination within jus in Bello maintains that 
for a war to be conducted in a just manner all military combatants shall discriminate enemy military from non-lethal innocent parties such as civilians [3]-[5]. Civilians should never be the targeted in attacks.

According to Howard Zinn [6], "It becomes difficult to sustain the claim that a war is just when both sides commit atrocities, unless one wants to argue that their atrocities are worse than ours." There is no doubt that the North was much more vicious in general. Yet, in many instances, the South and the UN acted no differently than the North, casting doubts on whether a war that saw such acts could be labeled just. One of the mostly widely recognized atrocities is the Jeju Uprising. Immediately after the invasion, the South Korean military ordered the preemptive apprehension of suspected leftists throughout the country. As there were many communist sympathizers on Jeju Island, thousands of suspected leftists were forced onto the island for special surveillance. People were classified into Groups A, B, C, or $\mathrm{D}$, based on the supposed threat they posed to the government On August 30, 1950, a letter was written by a senior intelligence officer that gave the order to "execute all those in groups C and D." [7] This decision was made only a month after the war broke out, and it was still unclear if the people placed into Groups C and D were actual sympathizers. Young men were executed on sight, women were gang raped, and $70 \%$ of Jeju Island's villages were burned to the ground. It is true that both Koreas committed atrocities; the only question is whether the discussion of same is balanced or not.

Another horrifying incident was the Bodo League Massacre. The Bodo League was a so-called re-education program for suspected communist sympathizers, initiated by President Rhee just before the Korean War. What was officially an educational organization was actually a system for oppressing political opposition. As the war broke out, the president's opponents and even their families were executed without trial and then dumped into trenches, mines, and the sea. This indicates that the war was manipulated as a tool to terminate political opposition and stabilize a tyrannical regime. All things considered, the conduct of war was unjust, as thousands of innocent civilians were intentionally targeted to fulfill a dictator's ambitions. To borrow Zinn's words again, asserting that either Korea took more just actions during the war than the other is no different than saying that the other side committed worse atrocities. Above all, a more unbiased application of the just war theory is necessary. Such an unbiased evaluation is only possible following the balanced acknowledgement of both sides' atrocities.

\section{CONCLUSION}

In reassessing the Korean War under the lens of the just war theory, this paper argues that the war was not clearly just. There were enough unjust elements to it to cast doubt on the justness of the war. The UN failed to represent a balanced voice, the belligerents' intentions could be viewed as hypocritical, and the conduct of the war was arguably malicious. These factors, which also show the forgotten side of South Korea and the UN during the war, deserve more attention if we expect to understand the nature of the Korean War from a wider perspective. As this paper demonstrates, the wider the perspective and the more available the information that is revealed, the harder it is to assert that one side was more 'just' than the other during the war.

There is no definite answer as to whether the Korean War was just or unjust, as it varies based on the respondents' perspectives. What has been regarded as the definite answer is that the war and its actions, from the perspective of South Korea, were just. However, this answer is based on the current South Korean cultural context and on the various historical conditions at the time. Taken into a broader context, the Korean War occurred at during the onset of the Cold War. This was a time when there were two definitive super powers with vastly different political and social ideals. In many ways the war represented a microcosm of the ideological power struggle between the Soviet Union and the United States. It's true that the Soviet Union did not involve itself in the war as much as the United States. However, the ideals of the North fell closer in line with the U.S.S.R while the South was clearly effected by the influence of the democratic leaning United States. As much as the United States earnestly desired to protect its ally in the South, it cannot be denied that their interests went beyond mere self-defense of an ally. There was real fear that of what might happen with continued communist expansion led by the Kremlin. When applying just war theory to this broader context it becomes less clear of whether the war was truly just as defined by the theory's principles.

Regardless of whether the U.S.' intentions were hypocritical or the UN was not sovereign enough, it was their decision to go to war that eventually enabled South Korea to flourish. Some also suggest that the war is now being justified based on South Korea's superior economic and diplomatic position. However, such a perspective only strengthens the political battle for the superiority of one side's political and economic systems. It's incorrect to deem a war just based on the current situation of the parties involved. By doing so the real causes and circumstances surrounding the war become clouded. To overcome this situation, as this paper shows, more attempts to reveal the past in an unbiased manner is required.

\section{REFERENCES}

[1] N. Fotion, War and Ethics: A New Just War Theory, London, UK: Continuum International Publishing Group, 2007.

[2] S. H. Choe, "Unearthing war's horrors years later in South Korea," The New York Times, December 3, 2007.

[3] M. Walzer, Just and Unjust Wars: A Moral Argument with Historical Illustrations, New York: Basic, 1977

[4] M. Walzer, Arguing about War, New Haven [Ct.: Yale UP, 2004 Print].

[5] N. Dower, The Ethics of War and Peace: Cosmopolitan and Other Perspectives, Cambridge, UK: Polity, 2009.

[6] United Nations, Charter of the United Nations.

[7] H. Zinn, "Just and Unjust War," [reprint] in Declarations of Independence: Cross-Examining American Ideology, New York: Perennial, 1991.

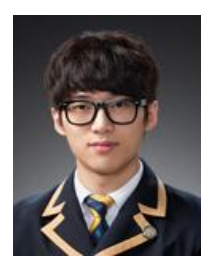

Hoeun Choi was born in Seoul, South Korea. He is student in Hankuk Academy of Foreign Studies, a premier college preparatory in South Korea. Within the school, he is most notably serving as the President of the HAFS Student Council. He has also worked for the Austrian Embassy and its affiliated multinational corporation, Lenzing Ltd. His research interests encompass leadership, politics and cultural anthropology, especially the post-colonial South Korea's struggle to redefine it amid the world superpowers. He wishes to apply the insights from those past experiences onto its modern leadership, and the manifestation of such interests has led to the research and the publication of this material. 